\section{Soy-composite Biocontainers Allow for Reduced Fertilizer Inputs during Container-crop Production}

\author{
Kenneth G. McCabe, James A. Schrader ${ }^{1}$, and Christopher J. Currey \\ Department of Horticulture, Iowa State University, 106 Horticulture Hall, \\ Ames, IA 50011 \\ David Grewell \\ Department of Agricultural and Biosystems Engineering, Iowa State \\ University, Ames, IA 50011
}

\section{William R. Graves \\ Department of Horticulture, Iowa State University, 106 Horticulture Hall, Ames, IA 50011}

Additional index words. biorenewable, potted crops, bioplastics, sustainability, marigold, mineral nutrition

\begin{abstract}
Bioplastics and bioplastic composites are a group of emerging sustainable materials that exhibit favorable characteristics for use in horticulture-production containers. Biocontainers made from composite materials of soy [Glycine max (L.) Merr.] bioplastic and poly(lactic) acid (PLA) have been shown to release nitrogen (N) at a rate suitable for supporting plant growth. We hypothesized that fertilizer applications can be reduced while maintaining adequate nutrition levels for plant production when using soy-based containers. To test this hypothesis and quantify potential reduction of fertilizer, we grew marigold 'Honeycomb' (Tagetes patula L.) in five prototypes of soycomposite biocontainers [soy bioplastic compounded with PLA or polyhydroxyalkanoates (PHA)] and a petroleum-plastic (polypropylene) control container with five fertilizer treatments supplying 1) $60 \mathrm{~N}-4 \mathrm{P}-49 \mathrm{~K}$; 2) $75 \mathrm{~N}-5 \mathrm{P}-61 \mathrm{~K}$; 3) $105 \mathrm{~N}-7 \mathrm{P}-85 \mathrm{~K}$; 4) $150 \mathrm{~N}-10 \mathrm{P}-122 \mathrm{~K}$; or 5) $300 \mathrm{~N}-20 \mathrm{P}-244 \mathrm{~K}$ mg. At harvest, plants grown in all soy-PLA composite biocontainers and protein + PLA biocontainers had higher concentrations and contents of $N$ and $P$ compared with plants grown in petroleum-plastic containers across all fertilizer treatments. Shoot $K$ concentrations were highest for plants grown in all soyPLA and soy-PHA biocontainers compared with plants grown in petroleum-plastic containers across all fertilizer treatments, whereas shoot $K$ concentrations in plants grown in protein + PLA biocontainers were equal to or lower than plants in petroleumplastic containers. Total plant dry weight was greater for plants grown in biocontainers made of $50 \%$ soy $-50 \%$ PLA and protein + PLA than for plants grown in control containers across all fertilizer treatments except at the highest rate of fertilizer in which plants received $300 \mathrm{~N}-20 \mathrm{P}-244 \mathrm{~K}$ mg. Our results support the hypothesis that fertilizer inputs can be reduced when using soy-composite biocontainers. Biocontainers made with equal parts soy bioplastic and PLA showed strong potential for achieving adequate plant growth with reduced fertilizer input. Our results demonstrate that fertilizer can be reduced by as much as $80 \%$ when growing marigold in containers made of $50 \%$ soy- $50 \%$ PLA for 6 weeks.
\end{abstract}

The bedding and garden plant industry, valued at $\$ 1.96$ billion in 2013 , represents a large portion of the containerized plant market (U.S. Department of Agriculture, 2014). A total of 609 million plants in containers were sold in 2013 from these two

Received for publication 22 Feb. 2016. Accepted for publication 26 May 2016

This research was supported in part by the National Institute of Food and Agriculture, USDA, Specialty Crops Research Initiative (award no. 2011-51181-30735) and by Iowa State University. We thank Peter Lawlor and Alexander Litvin for their helpful critiques of the manuscript.

${ }^{1}$ Corresponding author. E-mail: jschrade@iastate. edu.

plant categories, whereas $\approx 4$ billion containerized plants were sold throughout the entire container-crops industry. Because of the nearly universal dependence on petroleumplastic containers across the industry, production of these plants consumes $\approx 750$ million kilograms of petroleum-based plastic for single-use plant containers per year (Schrader, 2013; Schrader et al., 2013; U.S. Department of Agriculture, 2014). Along with the large consumption of petroleum-based materials, disposal of nondegradable plastics has many environmental drawbacks, especially considering that only $8.8 \%$ of plastic waste that enters the solid waste stream in the United States is recycled (Botts, 2007; Evans and Karcher, 2004; Helgeson et al., 2009; U.S. Environmental Protection Agency, 2013).
This heavy consumption and disposal of nonrenewable, nondegradable plastic has sparked concerns about the poor sustainability of container-crop production. In response to these problems with sustainability, producers and consumers of container crops are calling for the development of sustainable alternatives that can perform as well as, or better than, petroleum-plastic containers (Schrader et al., 2015b).

To address concerns surrounding petroleumplastic containers, biocontainers are being developed and evaluated as alternatives that are sustainable and biorenewable (Beeks and Evans, 2013a, 2013b; Evans and Karcher, 2004; Helgeson et al., 2009; Helgeson et al., 2010; Koeser et al., 2013a, 2013b; Kuehny et al., 2011; McCabe et al., 2014; Schrader et al., 2013). Many biocontainers are already commercially available, but the primary material of most is plant fiber, and such containers lead to poor water-use efficiency during plant production, inadequate structural strength when wet, and insufficient degradation in soil for end-of-life decomposition (Beeks and Evans, 2013b; Koeser et al., 2013b; McCabe et al., 2014). Newly developed biocontainers made from plant-protein and carbohydrate-based bioplastics show greater potential than traditional fiber-based biocontainers for use in container-crop production.

Soy-based bioplastics offer several advantages for container fabrication because soy materials are abundantly available, soybased bioplastics release plant-available nutrients, and soy-based copolymers can enhance degradation of other bioplastics (Grewell et al., 2014; Schrader et al., 2013; Yang et al., 2015). The components of soy-based bioplastics are soy flour $(\approx 50 \%$ protein), soy protein concentrate $(\approx 70 \%$ protein $)$, and/or soy protein isolate (SPI) ( $\geq 90 \%$ protein), all of which contain plant-essential primary macronutrients and micronutrients (U.S. Department of Agriculture, 2015). Although soy bioplastics offer many advantages compared with petroleum plastics, they do have some drawbacks. Potential issues are low stability in water and excessive nutrient release, coupled with rapid breakdown during plant production. These issues can be easily mitigated by compounding soy bioplastics with other more stable bioplastics such as PLA and PHA (Currey et al., 2014a; Grewell et al., 2014; Schrader et al., 2013). Previous bioplastic-container research has indicated that biocontainers made of composites of PLA and soy bioplastics exhibited satisfactory performance and additional functions over those of petroleum-plastic containers. The additional functions include intrinsic fertilizer release and root improvement of plants produced in composite biocontainers, as well as enhanced degradation in soil of compounded soy-PLA compared with pure PLA (Schrader et al., 2013; Yang et al., 2015).

PLA is a bioplastic that shows strong promise for container manufacturing and is the most widely produced industrial biopolymer. NatureWorks LLC (Minnetonka, MN), the largest producer of biopolymers in the 
world, can produce nearly 140 million kilograms of PLA annually and continues to increase their capacity (NatureWorks LLC, 2013a). This high production capacity demonstrates the potential of the bioplastics industry to supply sustainable materials that can begin to replace some of the 750 million kilograms of plastic required by the horticulture industry for containers (Schrader, 2013; Schrader et al., 2013; U.S. Department of Agriculture, 2014). PLA is durable and functionally very similar to petroleum plastics and comes in various formulations for specific applications. Life-cycle assessments of PLA have shown that PLA production consumes less nonrenewable energy and material resources and generates fewer greenhouse gas and acidic emissions than does petroleum plastics (Groot and Borén, 2010; Hermansson, 2013). PLA exhibits slow (1-2 years or more) or no biodegradation in soil, similar to petroleum plastic, but degradation can be improved by incorporation of biodegradable compounds (plant proteins, natural biomass fillers, and/or soy bioplastics) to facilitate endof-life options for disposal in soil (Grewell et al., 2014). Postconsumer PLA can also be converted to lactic acid and repolymerized without any loss of polymer integrity (NatureWorks LLC, 2013b).

Biocontainers made of high-percentage soy bioplastic ( $>50 \%$ soy) can degrade too quickly to be used in containers for greenhousecrop production and can release excessive ammoniacal N. Schrader et al. (2013) found that $\mathrm{N}$ concentrations in leachate collected after 3 weeks of greenhouse culture were $623 \mathrm{mg} \cdot \mathrm{L}^{-1}$ for high-percentage soy-bioplastic biocontainers ( $>50 \%$ soy bioplastic content) and was predominately ( $>99 \%$ ) in the form of $\mathrm{NH}_{4}^{+}$, a level of $\mathrm{NH}_{4}^{+}$that can negatively impact plant growth and cause ammonium toxicity. Leachate from plants growing in petroleum-plastic containers contained $68 \mathrm{mg} \cdot \mathrm{L}^{-1}$ of $\mathrm{N}$, which was mainly from $\mathrm{NO}_{3}^{-}$. The excessive $\mathrm{NH}_{4}^{+}$concentrations from high-percentage soy-bioplastic biocontainers resulted in stunted plants with smaller shoot size and lower plant dry weights than plants grown in soy-PLA (50\% soy-50\% PLA) composite biocontainers and petroleum-plastic containers (Schrader et al., 2013). Blending soy bioplastic with PLA reduced N release to 275 and $457 \mathrm{mg} \cdot \mathrm{L}^{-1}$ after 3 and 7 weeks, respectively, levels that are acceptable for production of greenhouse crops. Composites with equal parts soy bioplastic and PLA also showed increased structural durability compared with high-percentage soy-bioplastic biocontainers (Schrader et al., 2013).

To expand on previous research demonstrating nutrient-release characteristics from soy-composite biocontainers, we hypothesized that release of nutrients from bioplastics containing soy could allow for reduced fertilizer inputs during production of plants with short production cycles. To test this hypothesis, our objectives were to grow a common greenhouse-grown crop in various soy-composite biocontainers under a series of fertilizer treatments. We specifically aimed to evaluate plant growth and nutrient parameters of marigold grown in five soy-composite biocontainers and petroleum-plastic control containers under five fertilizer treatments. To understand the nutrient-release dynamics of the bioplastic material, we also evaluated nutrient disassociation of $\mathrm{N}, \mathrm{P}$, and $\mathrm{K}$ from bioplastic samples in water over time to elucidate the mechanism of nutrient release.

\section{Materials and Methods}

\section{Expt. 1. Container nutrition experiment}

Seeds of marigold 'Honeycomb' were sown in 288-celled plug trays (T.O. Plastics, Inc., Clearwater, MN) filled with a soilless germination substrate (Fafard Germination Mix; Sun Gro Horticulture, Agawam, MA). Once seedlings were $\approx 5 \mathrm{~cm}$ height, they were individually transplanted into five types of soy-composite biocontainers and one type of petroleum-plastic container filled with a soilless substrate (Sunshine ${ }^{\circledR}$ LB-2; Sun Gro Horticulture).

The container design was a smooth-walled round container with a flat bottom and four drainage holes, $11.4 \mathrm{~cm}$ top diameter, $9.7 \mathrm{~cm}$ height, a volume of $680 \mathrm{~mL}$, and the wall thickness of $1.5 \mathrm{~mm}$. The soy-composite biocontainers evaluated consisted of soy bioplastic compounded with Ingeo ${ }^{\mathrm{TM}}$ PLA 3001D (NatureWorks LLC) at a 50\%/50\% (by weight), soy bioplastic compounded with PLA at 33\%/ $67 \%$, soy bioplastic compounded with PLA at $30 \% / 60 \%$ with an additional $10 \%$ of dried distillers grains and solubles (DDGS) as a lowcost filler, and soy bioplastic compounded with PHA M2200 (Metabolix Inc., Cambridge, MA) at $33 \% / 67 \%$. The formulation for the soybioplastic component was SPI (26\%), soy flour $(26 \%)$, water $(31 \%)$, glycerin $(8 \%)$, phthalic anhydride (4\%), adipic acid (4\%), sodium sulfite $(1 \%)$, and potassium sorbate $(<1 \%)$. The PHA bioplastic was used for one of the composites because it is a unique bioplastic that is biodegradable, but we only developed one container formulation of soy-PHA because of high material cost and limited availability of PHA

Table 1. Five fertilizer treatments (TRT) administered by applying a $300 \mathrm{~mL}$ aliquot of a $16.6 \mathrm{~N}-5 \mathrm{P}-$ $16.3 \mathrm{~K}(\%)$ water-soluble fertilizer mixed to supply $\mathrm{N}\left(\mathrm{mg} \cdot \mathrm{L}^{-1}\right)$ at the corresponding fertilizer (Fert.) concentrations (concn) once weekly. The duration of time that the fertilizer was administered and the total mineral nutrients $[\mathrm{N}, \mathrm{P}$, and $\mathrm{K}(\mathrm{mg})]$ applied from that particular treatment are also included.

\begin{tabular}{|c|c|c|c|c|c|}
\hline \multirow[b]{2}{*}{ TRT } & \multirow[b]{2}{*}{ Fert. concn $\left(\mathrm{mg} \cdot \mathrm{L}^{-1} \mathrm{~N}\right)$} & \multirow[b]{2}{*}{ Duration } & \multicolumn{3}{|c|}{ Applied nutrient (mg) } \\
\hline & & & $\mathrm{N}$ & $\mathrm{P}$ & $\mathrm{K}$ \\
\hline$\overline{1^{z}}$ & 100 & 2 weeks only & 60 & 4 & 49 \\
\hline $2^{y}$ & 50 & 5 weeks & 75 & 5 & 61 \\
\hline $3^{x}$ & 100,50 & 2 weeks, 3 weeks & 105 & 7 & 85 \\
\hline $4^{\mathrm{w}}$ & 100 & 5 weeks & 150 & 10 & 122 \\
\hline $5^{\mathrm{v}}$ & 200 & 5 weeks & 300 & 20 & 244 \\
\hline
\end{tabular}

${ }^{2}$ Treatment regime was administered during the first 2 weeks of production to emulate the use of a shortterm fertilizer after transplanting.

${ }^{y}$ Treatment regime was administered to emulate a fertilizer regime supplying a low amount of fertilizer throughout the entire production cycle.

${ }^{x}$ Treatment regime was separated into two periods by supplying a moderate amount of fertilizer after transplanting for 2 weeks, then transitioning to a low amount for the remainder of the experiment (3 weeks).

wTreatment regime was administered to emulate a fertilizer regime supplying a moderate amount of fertilizer throughout the entire production cycle.

vTreatment regime was administered to emulate a fertilizer regime supplying a high amount of fertilizer throughout the entire production cycle. 
Kleve, Germany)]. Shoot nutrient content (mg) was calculated by multiplying concentration of nutrient $(\mathrm{mg} / \mathrm{g})$ in dried shoot tissue by shoot dry weight $(\mathrm{g})$.

\section{Expt. 2. Immersion of soy-bioplastic composite material in water}

To understand the mechanism of $\mathrm{N}, \mathrm{P}$, and $\mathrm{K}$ mineral nutrient release from soycomposite materials, samples of biocontainers were immersed in distilled deionized water for a total of 12 immersion durations $(0,1,2,4,8,16,24,32,48,72,96$, and $120 \mathrm{~h})$. Biocontainer samples (2 g sample for each replicate) consisted of two square pieces $(1 \times$ $1 \times 0.15 \mathrm{~cm}$ thick) that were cut from the sidewall of biocontainers made out of a mixture of soy bioplastic, PLA, and lignin (33\% soy bioplastic/67\% PLA/10\% lignin). Biocontainer samples were immersed in water by filling $60-\mathrm{mL}$ sealable vials with $50 \mathrm{~mL}$ of distilled deionized water and inserting the samples into solution for 1 of 12 immersion durations. Samples were selected randomly and immersed in treatment vials beginning with the longest immersion time $(120 \mathrm{~h})$ and finishing with the shortest immersion time $(0 \mathrm{~h})$ to ensure that all water samples were ready for analysis at the same time. The bioplastic samples were removed from all treatments immediately at the end of the experiment. For each immersion time, there was a set of untreated control units that contained distilled deionized water without a biocontainermaterial sample. The experiment was conducted in a plant growth chamber $(\mathrm{E}-41 \mathrm{HO}$; Percival Scientific, Perry, IA) in the dark at $20{ }^{\circ} \mathrm{C}$ and consisted of a total of four replicates (vials) for each immersion duration and treatment combination. The $\mathrm{pH}$ and electrical conductivity (EC) of samples were measured by using a handheld $\mathrm{pH}-\mathrm{EC}$ meter (HI 9813-6; Hanna Instruments, Smithfield, $\mathrm{RI}$ ), and were analyzed for concentrations of $\mathrm{N}, \mathrm{P}$, and $\mathrm{K}$ [N was determined using a flow injection analysis analyzer (8500 FIA; LACHAT Instruments, Loveland, CO) and P and $\mathrm{K}$ were determined using an ICP-OES (Optima 7300 V ICP-OES; PerkinElmer Inc., Waltham, MA)] at AgSource Harris Laboratories (Lincoln, NE).

Experimental design and statistical analysis. Experimental units were arranged in a completely randomized design in both experiments with $\mathrm{n}=5$ for each container type $\times$ fertilizer treatment in Expt. 1 and $n=4$ for each treatment $\times$ duration combination in Expt. 2. Analyses of variance and mean separation statistics were performed for all data using JMP ${ }^{\circledR}$ Statistical Software (version Pro 10; SAS Institute, Cary, NC). Mean separation was performed using Tukey's honestly significant difference test at $P \leq$ 0.05 . Regression analyses were performed using SigmaPlot (version 13; Systat Software, Inc., San Jose, CA).

\section{Results}

\section{Expt. 1. Container nutrition experiment}

Plant dry weight. Total dry weight was greater for plants grown in $50 \%$ soy-50\% PLA and protein + PLA biocontainers compared with plants in petroleum-plastic containers within all fertilizer treatments except the highest rate of $300 \mathrm{~N}-20 \mathrm{P}-244 \mathrm{~K} \mathrm{mg}$ (Table 2). At the lowest fertilizer rate (60N$4 \mathrm{P}-49 \mathrm{~K} \mathrm{mg}$ ), plants grown in biocontainers made of $50 \%$ soy $-50 \%$ PLA and protein + PLA accumulated greater total dry weight than plants in all other containers. No differences in

Table 2. Effect of container type and fertilizer treatment on total dry weight, shoot dry weight, and root dry weight of 'Honeycomb' marigold grown in five soycomposite biocontainers and a petroleum-plastic container. For clarity, treatments are expressed as total nutrients applied. ${ }^{\mathrm{z}}$

\begin{tabular}{|c|c|c|c|c|c|}
\hline \multirow[b]{2}{*}{ Container type ( $\%$ by wt) } & \multicolumn{5}{|c|}{ Fertilizer treatment (mg) } \\
\hline & $60 \mathrm{~N}-4 \mathrm{P}-49 \mathrm{~K}$ & $75 \mathrm{~N}-5 \mathrm{P}-61 \mathrm{~K}$ & $105 \mathrm{~N}-7 \mathrm{P}-85 \mathrm{~K}$ & $150 \mathrm{~N}-10 \mathrm{P}-122 \mathrm{~K}$ & $300 \mathrm{~N}-20 \mathrm{P}-244 \mathrm{~K}$ \\
\hline & \multicolumn{5}{|c|}{ Total dry weight (g) } \\
\hline Soy/PLA $-50 / 50$ & $9.2 \mathrm{~A}^{\mathrm{y}} \mathrm{b}^{\mathrm{x}}$ & $9.0 \mathrm{Ab}$ & $10.4 \mathrm{ABb}$ & $10.9 \mathrm{ABab}$ & $12.5 \mathrm{ABa}$ \\
\hline Soy/PLA-33/67 & $6.9 \mathrm{Bcd}$ & $6.6 \mathrm{BCd}$ & $8.2 \mathrm{Cbc}$ & $8.5 \mathrm{CDb}$ & $12.2 \mathrm{ABa}$ \\
\hline Soy/PLA + DDGS-30/60+10 & $7.1 \mathrm{Bc}$ & $7.8 \mathrm{ABc}$ & $9.8 \mathrm{Bb}$ & $9.5 \mathrm{BCb}$ & $12.6 \mathrm{Aa}$ \\
\hline Soy/PHA-33/67 & $5.0 \mathrm{Cbc}$ & $4.0 \mathrm{Dc}$ & $5.7 \mathrm{Db}$ & $6.4 \mathrm{Db}$ & $10.6 \mathrm{Ba}$ \\
\hline Protein + PLA (AR) & $9.4 \mathrm{Ac}$ & $9.7 \mathrm{Abc}$ & 11.4 Aabc & $11.9 \mathrm{Aab}$ & $12.7 \mathrm{Aa}$ \\
\hline Petroleum plastic & $5.6 \mathrm{BCc}$ & $5.1 \mathrm{CDc}$ & $7.6 \mathrm{Cb}$ & $8.4 \mathrm{CDb}$ & $12.4 \mathrm{ABa}$ \\
\hline Container (C) & $* * *$ & & & & \\
\hline Fertilizer $(\mathrm{F})$ & $* * *$ & & & & \\
\hline \multirow[t]{2}{*}{$\mathrm{C} \times \mathrm{F}$} & $* * *$ & & & & \\
\hline & \multicolumn{5}{|c|}{ Shoot dry weight (g) } \\
\hline Soy/PLA $-50 / 50$ & $7.0 \mathrm{Ac}$ & $6.7 \mathrm{Ac}$ & $7.7 \mathrm{ABbc}$ & $8.5 \mathrm{Aab}$ & $9.1 \mathrm{ABa}$ \\
\hline Soy/PLA-33/67 & $5.0 \mathrm{Bcd}$ & $4.4 \mathrm{Bd}$ & $5.3 \mathrm{Cbc}$ & 6.0 $\mathrm{CDb}$ & $8.3 \mathrm{BCa}$ \\
\hline Soy/PLA + DDGS-30/60+10 & $5.2 \mathrm{Bc}$ & $5.5 \mathrm{Bc}$ & $6.8 \mathrm{Bb}$ & $7.1 \mathrm{BCb}$ & $9.5 \mathrm{ABa}$ \\
\hline Soy/PHA-33/67 & $3.2 \mathrm{Cbc}$ & $2.4 \mathrm{Cc}$ & $3.7 \mathrm{Db}$ & $3.9 \mathrm{~Eb}$ & $7.4 \mathrm{Ca}$ \\
\hline Protein + PLA (AR) & $6.8 \mathrm{Ac}$ & $6.9 \mathrm{Abc}$ & $8.3 \mathrm{Aab}$ & 8.2 ABabc & $9.7 \mathrm{Aa}$ \\
\hline Petroleum plastic & $3.8 \mathrm{Cc}$ & $3.1 \mathrm{Cc}$ & $4.9 \mathrm{Cb}$ & $5.4 \mathrm{Db}$ & 8.5 $\mathrm{ABCa}$ \\
\hline Container (C) & $* * *$ & & & & \\
\hline Fertilizer $(\mathrm{F})$ & $* * *$ & & & & \\
\hline \multirow[t]{2}{*}{$\mathrm{C} \times \mathrm{F}$} & $* * *$ & & & & \\
\hline & \multicolumn{5}{|c|}{ Root dry weight (g) } \\
\hline Soy/PLA $-50 / 50$ & $2.2 \mathrm{ABb}$ & $2.3 \mathrm{ABab}$ & $2.7 \mathrm{ABab}$ & $2.4 \mathrm{Aab}$ & $3.4 \mathrm{Aa}$ \\
\hline Soy/PLA-33/67 & $1.9 \mathrm{ABb}$ & $2.2 \mathrm{ABb}$ & 2.9 ABab & $2.5 \mathrm{Ab}$ & $3.9 \mathrm{Aa}$ \\
\hline Soy/PLA + DDGS-30/60+10 & $1.9 \mathrm{ABb}$ & $2.3 \mathrm{ABab}$ & $3.0 \mathrm{ABa}$ & $2.4 \mathrm{Aab}$ & $3.1 \mathrm{Aa}$ \\
\hline Soy/PHA-33/67 & $1.8 \mathrm{ABb}$ & $1.6 \mathrm{Bb}$ & $2.0 \mathrm{Bb}$ & $2.5 \mathrm{Aab}$ & $3.2 \mathrm{Aa}$ \\
\hline Protein + PLA (AR) & $2.6 \mathrm{Aa}$ & $2.8 \mathrm{Aa}$ & $3.1 \mathrm{Aa}$ & $3.7 \mathrm{Aa}$ & $3.0 \mathrm{Aa}$ \\
\hline Petroleum plastic & $1.8 \mathrm{ABd}$ & $2.0 \mathrm{ABcd}$ & $2.7 \mathrm{ABbc}$ & $3.0 \mathrm{Ab}$ & $3.9 \mathrm{Aa}$ \\
\hline Container (C) & $* * *$ & & & & \\
\hline Fertilizer $(\mathrm{F})$ & $* *$ & & & & \\
\hline $\mathrm{C} \times \mathrm{F}$ & $*$ & & & & \\
\hline
\end{tabular}

$\mathrm{AR}=$ Aspen Research (Maple Grove, MN); DDGS = dried distiller's grains and solubles; PHA = polyhydroxyalkanoates; PLA = poly $($ lactic $)$ acid; Soy = soybased polymer.

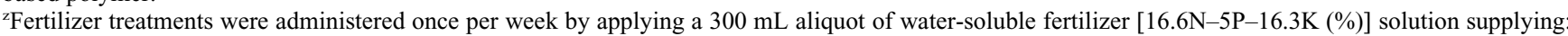

1) $100 \mathrm{mg} \cdot \mathrm{L}^{-1} \mathrm{~N}$ for the first 2 weeks followed by no fertilizer for the last 3 weeks $(60 \mathrm{~N}-4 \mathrm{P}-49 \mathrm{~K}$ mg applied in total);

2) $50 \mathrm{mg} \cdot \mathrm{L}^{-1} \mathrm{~N}$ for all 5 weeks $(75 \mathrm{~N}-5 \mathrm{P}-61 \mathrm{~K} \mathrm{mg}$ applied in total $)$;

3) $100 \mathrm{mg} \cdot \mathrm{L}^{-1} \mathrm{~N}$ for the 2 weeks followed by $50 \mathrm{mg} \cdot \mathrm{L}^{-1} \mathrm{~N}$ for the last 3 weeks $(105 \mathrm{~N}-7 \mathrm{P}-85 \mathrm{~K}$ mg applied in total);

4) $100 \mathrm{mg} \cdot \mathrm{L}^{-1} \mathrm{~N}$ for all 5 weeks $(150 \mathrm{~N}-10 \mathrm{P}-122 \mathrm{~K} \mathrm{mg}$ applied in total);or

5) $200 \mathrm{mg} \cdot \mathrm{L}^{-1} \mathrm{~N}$ for all 5 weeks $(300 \mathrm{~N}-20 \mathrm{P}-244 \mathrm{~K} \mathrm{mg}$ applied in total).

y Uppercase letters indicate mean separation within a fertilizer treatment across container type by Tukey's honestly significant difference test at $P \leq 0.05$.

${ }^{x}$ Lowercase letters indicate mean separation within a container type across fertilizer treatment by Tukey's honestly significant difference test at $P \leq 0.05$.

$*, * *, * * *$ Significant at $P \leq 0.05,0.01$, or 0.001 , respectively. 
dry weight were observed across container treatments when units were supplied with the highest rate of fertilizer $(300 \mathrm{~N}-20 \mathrm{P}-$ $244 \mathrm{~K} \mathrm{mg}$ ), except that dry weight was lower for plants grown in containers made of soyPHA. Plants produced in 33\% soy-67\% PLA biocontainers had similar dry weight to plants produced in petroleum-plastic containers across all fertilizer treatments. Plants grown in soy-PHA biocontainers had less dry weight compared with plants in petroleum-plastic containers when fertilized with $105 \mathrm{~N}-7 \mathrm{P}-85 \mathrm{~K}$ or $300 \mathrm{~N}-20 \mathrm{P}-244 \mathrm{~K}$ mg (Table 2).

Shoot dry weight was greater for plants grown in biocontainers made of 50\% soy$50 \%$ PLA and protein + PLA than for those grown in all other container types when provided the two lowest rates of fertilizer, $60 \mathrm{~N}-4 \mathrm{P}-49 \mathrm{~K}$ and $75 \mathrm{~N}-5 \mathrm{P}-61 \mathrm{~K} \mathrm{mg}$ (Table 2). At the lowest rate of fertilizer ( $60 \mathrm{~N}-$ $4 \mathrm{P}-49 \mathrm{~K} \mathrm{mg}$ ), shoot dry weight of plants grown in $50 \%$ soy $-50 \%$ PLA biocontainers $(7.0 \mathrm{~g})$ and protein + PLA biocontainers $(6.8 \mathrm{~g})$ was $\approx 1.8$ times greater than plants grown in petroleum-plastic containers $(3.8 \mathrm{~g})$. No differences in shoot dry weight were noted for plants in any of the container types when fertilizer was supplied at the highest rate of $300 \mathrm{~N}-20 \mathrm{P}-244 \mathrm{~K} \mathrm{mg}$ (Table 2; Fig. 1). There were no differences in root dry weight across any of the container or fertilizer treatments, except that root dry weight was lower for plants grown in soy-PHA biocontainers than for plants in protein + PLA biocontainers when provided fertilizer at the $75 \mathrm{~N}-5 \mathrm{P}-61 \mathrm{~K}$ and $105 \mathrm{~N}-7 \mathrm{P}-85 \mathrm{~K} \mathrm{mg}$ (Table 2).

Shoot nutrient concentration. Shoot N concentrations were 1.5 to 4.1 times greater for plants grown in 50\% soy-50\% PLA biocontainers than for plants grown in petroleumplastic containers when provided fertilizer rates of $300 \mathrm{~N}-20 \mathrm{P}-244 \mathrm{~K}$ to $60 \mathrm{~N}-4 \mathrm{P}-49 \mathrm{~K} \mathrm{mg}$ (Table 3). Within each fertilizer rate treatment, plants grown in containers made of $50 \%$ soy$50 \%$ PLA, protein + PLA, and soy-PLA + DDGS had higher concentrations of $\mathrm{N}$ in their shoots than did plants grown in petroleumplastic containers. Plants grown in biocontainers with reduced amounts of soy bioplastic (33\% soy-67\% PLA, soy-PLA + DDGS, and soy-PHA) had lower shoot $\mathrm{N}$ concentrations than plants in $50 \%$ soy-50\% PLA biocontainers across all fertilizer treatments except for plants grown in soy-PLA + DDGS biocontainers when supplied with fertilizer at $300 \mathrm{~N}-20 \mathrm{P}-244 \mathrm{~K} \mathrm{mg}$ (Table 3). Visual indication of low $\mathrm{N}$ concentration (chlorosis) was evident in shoots of plants grown in soy-PHA and petroleum-plastic containers that were provided with the lowest rate of fertilizer, $60 \mathrm{~N}-$ 4P-49K mg (Fig. 1).

Within each fertilizer treatment, shoot $\mathrm{P}$ concentrations were greater for plants produced in all biocontainers than for those grown in to petroleum-plastic containers, except for plants grown in soy-PHA containers at the highest rate of fertilizer, $300 \mathrm{~N}-$ 20P-244K mg (Table 3). Plants grown in biocontainers made from protein + PLA had the greatest shoot $\mathrm{P}$ concentration compared

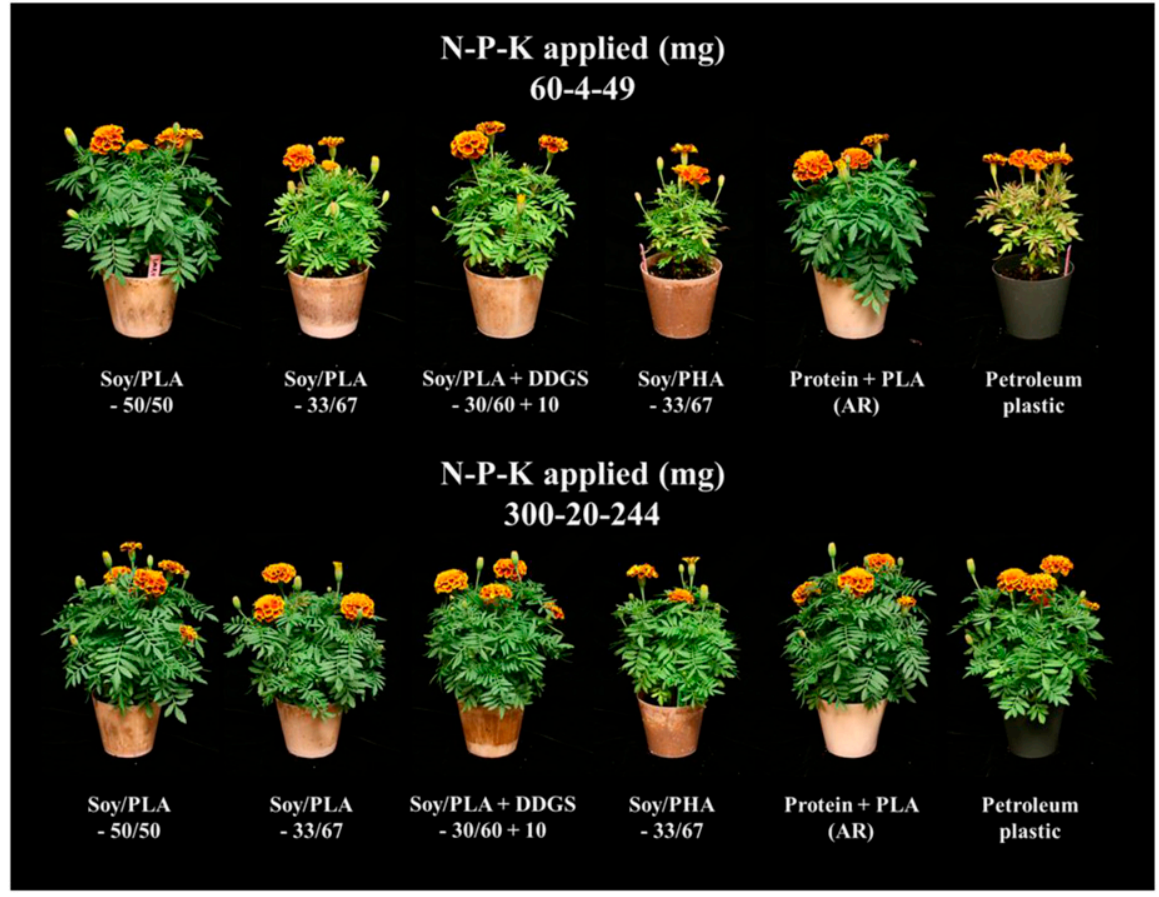

Fig. 1. 'Honeycomb' marigold (Tagetes patula) plants grown in five soy-composite biocontainers and petroleum-plastic containers and provided our lowest rate (top row) and highest rate (bottom row) of five water-soluble fertilizer treatments. The lowest fertilizer rate supplied a total amount of $60 \mathrm{~N}-4 \mathrm{P}-$ $49 \mathrm{~K} \mathrm{mg}$, and the highest fertilizer rate supplied a total amount of $300 \mathrm{~N}-20 \mathrm{P}-244 \mathrm{~K} \mathrm{mg}$. The various soy-composite biocontainers consisted of soy bioplastic compounded with poly(lactic) acid (PLA) at $50 \%$ soy bioplastic-50\% PLA (by weight), soy bioplastic compounded with PLA at $33 \%$ soy bioplastic- $67 \%$ PLA, soy bioplastic compounded with PLA at 30\% soy bioplastic-60\% PLA with an additional $10 \%$ of dried distillers grains and solubles (DDGS), soy bioplastic compounded with polyhydroxyalkanoates (PHA) at 33\% soy bioplastic-67\% PHA, and a proprietary bioplastic material of protein + PLA provided by Aspen Research Inc. (AR) of Maple Grove, MN. The petroleum-plastic containers were made of polypropylene.

with plants grown in all other container types in each fertilizer treatment.

Within each fertilizer treatment, plants grown in all bioplastic container types had higher concentrations of $\mathrm{K}$ in their shoots than did plants grown in petroleum-plastic containers, except that plants grown in protein + PLA had shoot K concentrations that were either lower or not different from those grown in petroleum-based containers (Table 3). Across fertilizer treatments, shoot K concentrations were 1.5 to 2.2 times greater for plants grown in 50\% soy-50\% PLA biocontainers than for plants grown in petroleum-plastic containers. The lowest concentration of $\mathrm{K}$ was in plants produced in protein + PLA biocontainers and provided with $75 \mathrm{~N}-5 \mathrm{P}-61 \mathrm{~K}$ or $105 \mathrm{~N}-7 \mathrm{P}-85 \mathrm{~K} \mathrm{mg}$ (Table 3).

Shoot nutrient content. Because shoot dry weight varied across container and fertilizer treatments, we calculated nutrient content of shoots to determine the amount of each nutrient that was taken up and stored in shoot tissues. Across fertilizer treatments, shoot $\mathrm{N}$ content was 1.6 to 7.7 times greater for plants grown in $50 \%$ soy- $50 \%$ PLA biocontainers than for plants grown in petroleum-plastic containers (Table 4). The N content for plants grown in soy-PHA biocontainers was similar to plants grown in petroleum-plastic containers. Marigolds in 50\% soy-50\% PLA biocontainers and protein + PLA biocontainers had the highest $\mathrm{N}$ content across all fertilizer treatments, except that plants in soy-PLA + DDGS biocontainers had similar $\mathrm{N}$ content at the highest fertilizer rate of $300 \mathrm{~N}-20 \mathrm{P}-244 \mathrm{~K}$ mg (Table 4).

Plants grown in $50 \%$ soy- $-50 \%$ PLA biocontainers also had 1.6 to 5.0 times greater $\mathrm{P}$ content across fertilizer treatments compared with plants in petroleum-plastic containers, whereas plants grown in protein + PLA containers had the highest shoot $\mathrm{P}$ content across all fertilizer treatments when compared with all other container types (Table 4). Plants produced in soy-PHA biocontainers had similar P content to plants in petroleum-plastic containers when fertilized with $105 \mathrm{~N}-7 \mathrm{P}-85 \mathrm{~K}$, $150 \mathrm{~N}-10 \mathrm{P}-122 \mathrm{~K}$, or $300 \mathrm{~N}-20 \mathrm{P}-244 \mathrm{~K}$ mg.

Shoot $\mathrm{K}$ content was also greater (1.6 to 4.0 times) for plants produced in $50 \%$ soy$50 \%$ PLA biocontainers compared with plants in petroleum-plastic containers (Table 4). Plants produced in $50 \%$ soy- $50 \%$ PLA biocontainers had the highest shoot $\mathrm{K}$ content compared with plants in all other container types across all fertilizer treatments, except for plants fertilized with $300 \mathrm{~N}-20 \mathrm{P}-244 \mathrm{~K} \mathrm{mg}$ and grown in soy-PLA + DDGS biocontainers. Shoot K content was lower for plants grown in protein + PLA biocontainers across fertilizer treatments than for most biocontainers, but was similar or slightly greater than $\mathrm{K}$ contents for 
Table 3. Effect of container type and fertilizer treatment on N, P, and K shoot concentration of 'Honeycomb' marigold grown in five soy-composite biocontainers and a petroleum-plastic container. For clarity, treatments are expressed as total nutrients applied. ${ }^{z}$

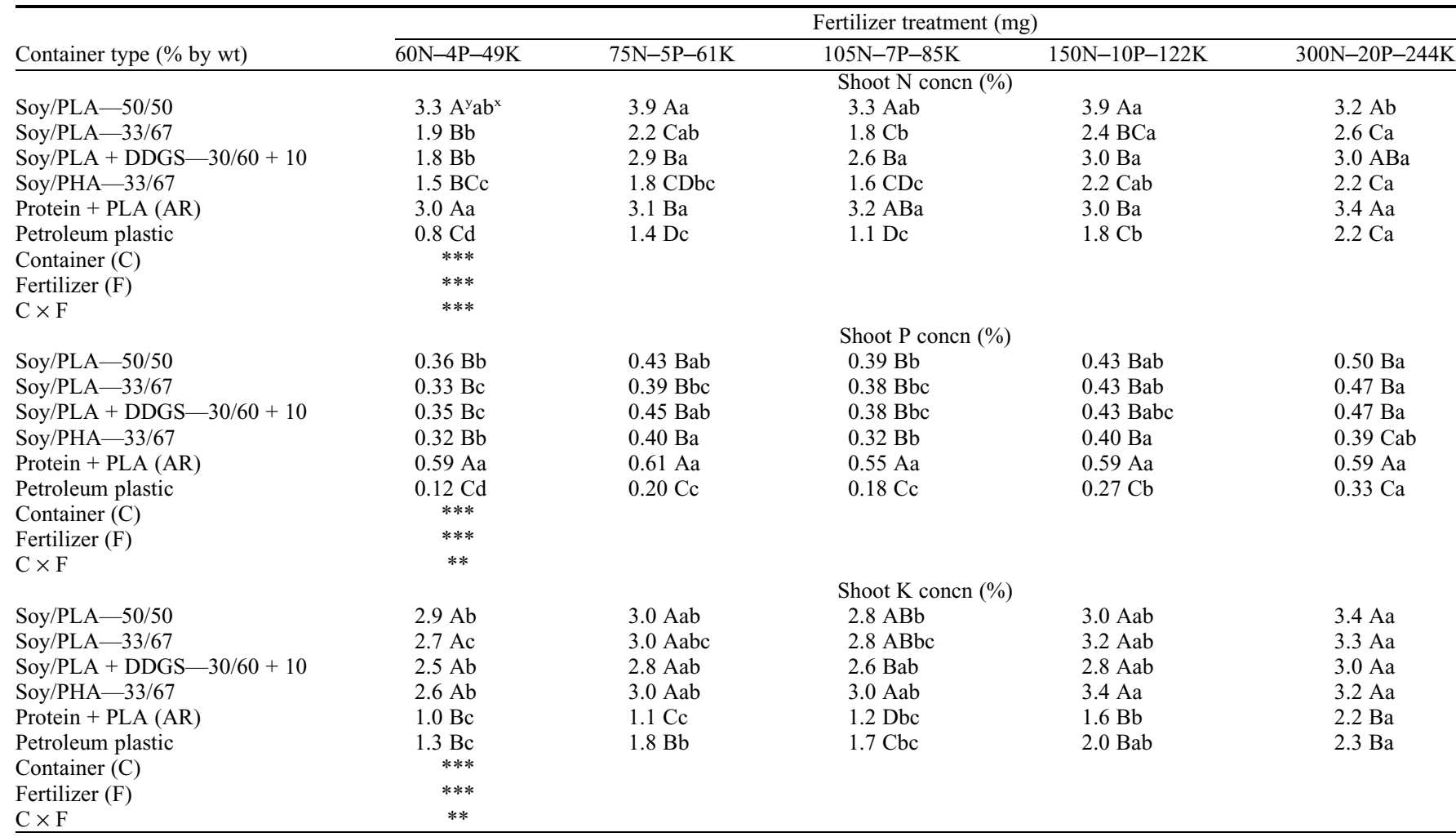

AR = Aspen Research (Maple Grove, MN); DDGS = dried distiller's grains and solubles; PHA = polyhydroxyalkanoates; PLA = poly $($ lactic $)$ acid; Soy = soybased polymer.

${ }^{2}$ Fertilizer treatments were administered once per week by applying a $300 \mathrm{~mL}$ aliquot of water-soluble fertilizer [16.6N-5P-16.3K (\%)] solution supplying: 1 ) 100 $\mathrm{mg} \cdot \mathrm{L}^{-1} \mathrm{~N}$ for the first 2 weeks followed by no fertilizer for the last 3 weeks $(60 \mathrm{~N}-4 \mathrm{P}-49 \mathrm{~K} \mathrm{mg}$ applied in total); 2$) 50 \mathrm{mg} \cdot \mathrm{L}^{-1} \mathrm{~N}$ for all $5 \mathrm{weeks}(75 \mathrm{~N}-5 \mathrm{P}-61 \mathrm{~K}$ mg applied in total); 3) $100 \mathrm{mg} \cdot \mathrm{L}^{-1} \mathrm{~N}$ for the 2 weeks followed by $50 \mathrm{mg} \cdot \mathrm{L}^{-1} \mathrm{~N}$ for the last 3 weeks $(105 \mathrm{~N}-7 \mathrm{P}-85 \mathrm{~K} \mathrm{mg}$ applied in total); 4$) 100 \mathrm{mg} \cdot \mathrm{L}^{-1} \mathrm{~N}$ for all 5 weeks $\left(150 \mathrm{~N}-10 \mathrm{P}-122 \mathrm{~K} \mathrm{mg}\right.$ applied in total); or 5) $200 \mathrm{mg} \cdot \mathrm{L}^{-1} \mathrm{~N}$ for all 5 weeks $(300 \mathrm{~N}-20 \mathrm{P}-244 \mathrm{~K}$ mg applied in total).

' Uppercase letters indicate mean separation within a fertilizer treatment across container type by Tukey's honestly significant difference test at $P \leq 0.05$. ${ }^{x}$ Lowercase letters indicate mean separation within a container type across fertilizer treatment by Tukey's honestly significant difference test at $P \leq 0.05$. **, ***Significant at $P \leq 0.01$, or 0.001 , respectively.

plants grown in petroleum-plastic containers (Table 4).

\section{Expt. 2. Immersion of soy-bioplastic composite material in water}

In Expt. 2, pH of water samples containing soy-composite biocontainer material decreased initially then leveled off, and the $\mathrm{pH}$ of water-only samples decreased slightly but remained near the same level $(\mathrm{pH} \approx 5.8)$ regardless of duration (Fig. 2). The EC for water samples containing biocontainer material increased with an increase in immersion duration, while no ions were detected for samples that contained water only $(\mathrm{EC}=0)$ (Fig. 3). The EC in samples that contained biocontainer material increased the most during the first $48 \mathrm{~h}$ of immersion and then slowed, but still continued to increase gradually through $120 \mathrm{~h}$ (Fig. 3). Similar to EC, concentrations of both $\mathrm{P}$ and $\mathrm{K}$ increased over time, whereas concentration of $\mathrm{N}$ was unaffected by duration. Concentrations of $\mathrm{P}$ and $\mathrm{K}$ increased similarly and were at similar concentrations throughout the $120 \mathrm{~h}$ of the experiment (Fig. 4). Concentrations of $\mathrm{P}$ and $\mathrm{K}$ increased rapidly within the first $48 \mathrm{~h}$ and followed a similar trend when compared with EC readings over time (Figs. 3 and 4).

\section{Discussion}

The development and implementation of sustainable alternatives to petroleum-plastic for horticulture-production containers has been hindered by the reluctance of growers and producers to change their practices (Koeser et al., 2013a). This issue may diminish with the introduction of new containers made of bioplastics and biocomposites that perform similarly or better than petroleum-plastic containers. Soy-composite biocontainers have additional functions compared with petroleumplastic containers beyond material renewability, and this could be a driving force that triggers expanded use of biocontainers for plant production. Use of soy-composite biocontainers can provide new end-of-life options for container disposal (Kratsch et al., 2015; Schrader et al., 2015a) and can enhance transplant establishment because of improvements in root structure and growth (Schrader et al., 2013). Results from our experiments confirm the findings of Schrader et al. (2013) that biocontainers made of soy-based bioplastic composites can provide plant-available nutrients. Our results further demonstrate that fertilizer inputs can be reduced during production of marigold in soy-based biocontainers with no reduction in crop growth or mineral content (Tables 2-4; Fig. 1). These are all added benefits that may allow growers and producers to market plants grown in soy-composite biocontainers in various niche markets and produce plants more sustainably while becoming less dependent on finite, fossil-based resources.

The potential for reduction in fertilizer inputs facilitated by the nutrient provision of soy-composite biocontainers is an advancement that could greatly improve the sustainability of short-term container-crop production. Most synthetic $\mathrm{N}$ fertilizers are manufactured by the Haber-Bosch process, a system that consumes large amounts of fossil-fuel energy (Pelletier et al., 2011; Razon, 2014). The N supplied from soy-bioplastics is a product of biological $\mathrm{N}$ fixation in the root nodules of soybean, a process ultimately fueled by energy from the sun through photosynthesis. On the basis of research with agronomic systems, it is estimated that using plant-derived $\mathrm{N}$ fertilizers could reduce energy usage, global warming impact, ozone depletion, and acidic emissions by $7.9,6.4,935$, and 1.8 times, respectively, when compared with synthetic $\mathrm{N}$ fertilizers (Pelletier et al., 2008; Yang et al., 2015). Beyond the benefits of fertilizer source, intrinsic fertilizer supplied by soy-composite 
Table 4. Effect of container type and fertilizer treatment on N, P, and K shoot content of 'Honeycomb' marigold grown in five soy-composite biocontainers and a petroleum-plastic container. For clarity, treatments are expressed as total nutrients applied. ${ }^{z}$

\begin{tabular}{|c|c|c|c|c|c|}
\hline \multirow[b]{2}{*}{ Container type (\% by wt) } & \multicolumn{5}{|c|}{ Fertilizer treatment $(\mathrm{mg})$} \\
\hline & $60 \mathrm{~N}-4 \mathrm{P}-49 \mathrm{~K}$ & $75 \mathrm{~N}-5 \mathrm{P}-61 \mathrm{~K}$ & $105 \mathrm{~N}-7 \mathrm{P}-85 \mathrm{~K}$ & $150 \mathrm{~N}-10 \mathrm{P}-122 \mathrm{~K}$ & $300 \mathrm{~N}-20 \mathrm{P}-244 \mathrm{~K}$ \\
\hline Soy/PLA—50/50 & $227 \mathrm{~A}^{y} \mathrm{c}^{\mathrm{x}}$ & $253 \mathrm{Abc}$ & $254 \mathrm{Abc}$ & $333 \mathrm{Aa}$ & $288 \mathrm{ABab}$ \\
\hline Soy/PHA—33/67 & $46 \mathrm{Cc}$ & $42 \mathrm{Ec}$ & $58 \mathrm{Cc}$ & $85 \mathrm{~Eb}$ & $165 \mathrm{Ca}$ \\
\hline Protein + PLA (AR) & $203 \mathrm{Ab}$ & $213 \mathrm{Bb}$ & $261 \mathrm{Ab}$ & $245 \mathrm{Ab}$ & $333 \mathrm{Aa}$ \\
\hline Petroleum plastic & $30 \mathrm{Cd}$ & $44 \mathrm{Ec}$ & $56 \mathrm{Cc}$ & $95 \mathrm{~Eb}$ & $184 \mathrm{Ca}$ \\
\hline \multirow[t]{2}{*}{$\mathrm{C} \times \mathrm{F}$} & $* * *$ & & & & \\
\hline & \multicolumn{5}{|c|}{ Shoot $\mathrm{P}$ content $(\mathrm{mg})$} \\
\hline Soy/PLA—50/50 & $25 \mathrm{Bd}$ & $27 \mathrm{Bcd}$ & $30 \mathrm{Bc}$ & $37 \mathrm{Bb}$ & $45 \mathrm{Ba}$ \\
\hline Soy/PLA—33/67 & $16 \mathrm{Cd}$ & $17 \mathrm{Ccd}$ & $20 \mathrm{Cc}$ & $26 \mathrm{Db}$ & $38 \mathrm{Ca}$ \\
\hline Soy/PLA + DDGS-30/60+10 & $18 \mathrm{Cd}$ & $29 \mathrm{Bc}$ & $26 \mathrm{Bc}$ & $30 \mathrm{Cb}$ & $45 \mathrm{Ba}$ \\
\hline Soy/PHA—33/67 & $9 \mathrm{Dc}$ & $10 \mathrm{Dc}$ & $11 \mathrm{Dc}$ & $15 \mathrm{~Eb}$ & $28 \mathrm{Da}$ \\
\hline Protein + PLA (AR) & $40 \mathrm{Ac}$ & $42 \mathrm{Abc}$ & $46 \mathrm{Abc}$ & $48 \mathrm{Ab}$ & $57 \mathrm{Aa}$ \\
\hline $\mathrm{C} \times \mathrm{F}$ & \multicolumn{5}{|c|}{ Shoot $\mathrm{K}$ content (mg) } \\
\hline Soy/PLA—50/50 & $198 \mathrm{Ac}$ & $194 \mathrm{Ac}$ & $213 \mathrm{Ac}$ & $255 \mathrm{Ab}$ & $312 \mathrm{Aa}$ \\
\hline Soy/PLA—33/67 & $135 \mathrm{Bc}$ & $133 \mathrm{Cc}$ & $150 \mathrm{Cc}$ & $193 \mathrm{Bb}$ & $270 \mathrm{Ba}$ \\
\hline Soy/PLA + DDGS-30/60 + 10 & $127 \mathrm{Be}$ & 154 Bd & $175 \mathrm{Bc}$ & $201 \mathrm{Bb}$ & $283 \mathrm{ABa}$ \\
\hline Soy/PHA-33/67 & $81 \mathrm{Ccd}$ & $72 \mathrm{DEd}$ & $107 \mathrm{Dbc}$ & $130 \mathrm{Cb}$ & $236 \mathrm{Ca}$ \\
\hline Protein + PLA (AR) & $66 \mathrm{Dd}$ & 73 Dd & $96 \mathrm{DEc}$ & $127 \mathrm{Cb}$ & $216 \mathrm{CDa}$ \\
\hline Petroleum plastic & $50 \mathrm{Ed}$ & $56 \mathrm{Ed}$ & $82 \mathrm{Ec}$ & $109 \mathrm{Cb}$ & $195 \mathrm{Da}$ \\
\hline Container (C) & $* * *$ & & & & \\
\hline Fertilizer (F) & $* * *$ & & & & \\
\hline $\mathrm{C} \times \mathrm{F}$ & $* *$ & & & & \\
\hline
\end{tabular}

AR = Aspen Research (Maple Grove, MN); DDGS = dried distiller's grains and solubles; PHA = polyhydroxyalkanoates; PLA = poly (lactic) acid; Soy = soybased polymer.

${ }^{2}$ Fertilizer treatments were administered once per week by applying a $300 \mathrm{~mL}$ aliquot of water-soluble fertilizer [16.6N-5P-16.3K (\%)] solution supplying: 1) 100 $\mathrm{mg} \cdot \mathrm{L}^{-1} \mathrm{~N}$ for the first 2 weeks followed by no fertilizer for the last 3 weeks $(60 \mathrm{~N}-4 \mathrm{P}-49 \mathrm{~K} \mathrm{mg}$ applied in total); 2$) 50 \mathrm{mg} \cdot \mathrm{L}^{-1} \mathrm{~N}$ for all $5 \mathrm{weeks}(75 \mathrm{~N}-5 \mathrm{P}-61 \mathrm{~K}$ mg applied in total); 3) $100 \mathrm{mg} \cdot \mathrm{L}^{-1} \mathrm{~N}$ for the 2 weeks followed by $50 \mathrm{mg} \cdot \mathrm{L}^{-1} \mathrm{~N}$ for the last 3 weeks $(105 \mathrm{~N}-7 \mathrm{P}-85 \mathrm{~K} \mathrm{mg}$ applied in total); 4$) 100 \mathrm{mg} \cdot \mathrm{L}^{-1} \mathrm{~N}$ for all 5 weeks $\left(150 \mathrm{~N}-10 \mathrm{P}-122 \mathrm{~K} \mathrm{mg}\right.$ applied in total); or 5) $200 \mathrm{mg} \cdot \mathrm{L}^{-1} \mathrm{~N}$ for all 5 weeks $(300 \mathrm{~N}-20 \mathrm{P}-244 \mathrm{~K}$ mg applied in total).

yUppercase letters indicate mean separation within a fertilizer treatment across container type by Tukey's honestly significant difference test at $P \leq 0.05$. ${ }^{x}$ Lowercase letters indicate mean separation within a container type across fertilizer treatment by Tukey's honestly significant difference test at $P \leq 0.05$. **, ***Significant at $P \leq 0.01$, or 0.001 , respectively.

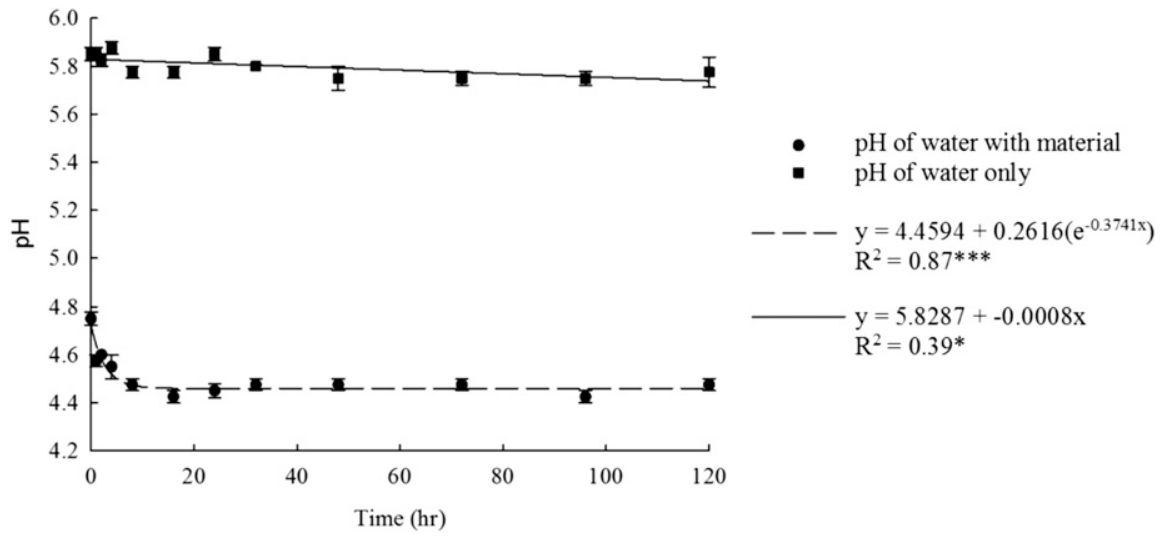

Fig. 2. The $\mathrm{pH}$ of $50-\mathrm{mL}$ water samples $(\mathrm{n}=4)$ that contained either $2 \mathrm{~g}$ of soy-composite biocontainer material or water only across 12 immersion durations $(0,1,2,4,8,16,24,32,48,72,96$, and $120 \mathrm{~h})$. *** Significant at $P \leq 0.001$.

biocontainers could also facilitate reductions in cost and labor that are directly associated with fertilizer application during plant production. If fertilizer is provided by the container, the need for fertilizer application can be reduced or eliminated.

In our trials, plant growth varied with the type of soy-composite biocontainer used. Of the five biocontainer types we evaluated, two materials (50\% soy- $50 \%$ PLA and protein + PLA) provided suitable amounts of fertilizer nutrients for growth of marigolds when supplied supplemental fertilizer as low as 100 $\mathrm{mg} \cdot \mathrm{L}^{-1} \mathrm{~N}$ once per week for 2 weeks only $(60 \mathrm{~N}-4 \mathrm{P}-49 \mathrm{~K} \mathrm{mg})$, the lowest fertilizer rate in the experiment (Table 2; Fig. 1). Fertilizer provided from these two biocontainer types was enough to sustain similar plant growth under the lowest fertilizer level $(60 \mathrm{mg} \mathrm{N})$ when compared with plants that were grown in petroleum-plastic containers provided with a more typical amount of fertilizer (200 mg. $\mathrm{L}^{-1} \mathrm{~N}$ once per week for 6 weeks$300 \mathrm{mg} \mathrm{N}$ ). Shoot N content was also greater in many of the plants grown in soy-composite biocontainers compared with the amount of $\mathrm{N}$ applied for each fertilizer treatment (Table 4). This indicates the potential to reduce fertilizer inputs by as much as $80 \%$ when growing common species such as marigold.

Currey et al. (2014b) have shown that it takes a short time for the intrinsic $\mathrm{N}$ from soycomposite biocontainers to become available to plants and that some type of fertilizer will be required during early stages of plant production. We have demonstrated that fertilizer applications of 50-100 mg. $\mathrm{L}^{-1} \mathrm{~N}$ are sufficient for meeting the nutrient needs of marigold grown in soy-composite containers during early stages of growth, but can be discontinued $\approx 2$ weeks after transplant. This lag time in nutrient availability from soycomposite containers may be because both physical and microbial breakdown of the soybioplastic fraction is required for release of plant-available nutrients. We have demonstrated in Expt. 2 (immersion of soy-composite material in water) that physical breakdown 


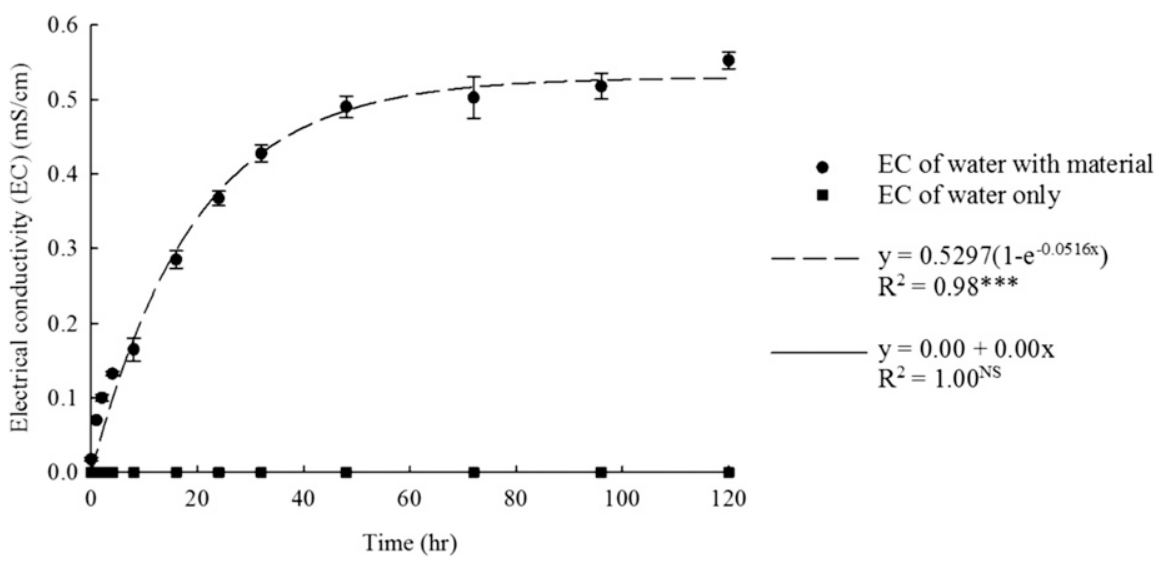

Fig. 3. Electrical conductivity of $50-\mathrm{mL}$ water samples $(\mathrm{n}=4)$ that contained either $2 \mathrm{~g}$ of soy-composite biocontainer material or water only across 12 immersion durations $(0,1,2,4,8,16,24,32,48,72,96$, and $120 \mathrm{~h}) . * *$, ${ }^{\text {ss }}$ Significant at $P \leq 0.001$ or nonsignificant, respectively.

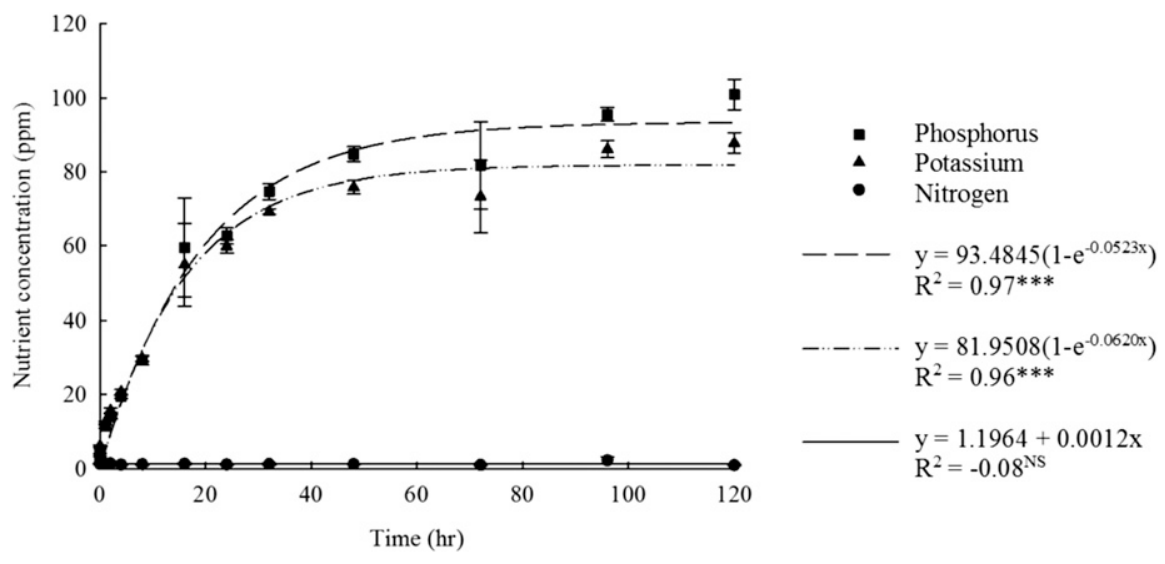

Fig. 4. Nutrient release of nitrogen, phosphorus, and potassium in $50-\mathrm{mL}$ water samples $(\mathrm{n}=4)$ that contained $2 \mathrm{~g}$ of soy-composite biocontainer material across 12 immersion durations $(0,1,2,4,8,16$, $24,32,48,72,96$, and $120 \mathrm{~h}) .{ }^{* * *}$, Ns Significant at $P \leq 0.001$ or nonsignificant, respectively.

can cause release of $\mathrm{P}$ and $\mathrm{K}$. When examining concentration of $\mathrm{N}$ compared with $\mathrm{P}$ or $\mathrm{K}$, there was no increase of $\mathrm{N}$ in the controlled aqueous environment, whereas both $\mathrm{P}$ and $\mathrm{K}$ increased over time (Fig. 4). This is in agreement with Calabria et al. (2012) who found that a bioplastic blend of SPI and PLA released ions (did not differentiate between $\mathrm{N}$, $\mathrm{P}$, and $\mathrm{K}$ ) into an aqueous solution over time, contributing to an elevated EC. This suggests that $\mathrm{P}$ and $\mathrm{K}$ may be readily released through nutrient disassociation in an aqueous environment, but $\mathrm{N}$ release likely requires microbial breakdown of the proteins in soy bioplastic. Schrader et al. (2013) found $\mathrm{NH}_{4}{ }^{+}$and $\mathrm{NO}_{3}{ }^{-}$ were present in leachate collected from soycomposite biocontainers after 3 and 7 weeks of culture in a greenhouse, with higher proportions of $\mathrm{NH}_{4}^{+}$early ( 3 weeks) in production and higher proportions of $\mathrm{NO}_{3}^{-}$later (7 weeks), suggesting microbial conversion of $\mathrm{N}$ may be taking place by nitrifying microorganisms. Our results suggest that the short lag time ( $\approx 2$ weeks) before sufficient levels of $\mathrm{N}$ are available could be compensated for by using growing substrates that contain a starter fertilizer charge. Use of soy-composite biocontainers in combination with substrates containing a starter charge may allow growers to eliminate supplemental fertilizer and irrigate with water only during the entire crop cycle.

Our results also indicate that bioplastic materials that are relatively stable may be better suited for compounding with soy bioplastic than other, less stable bioplastics. Soy bioplastic compounded with PLA at $33 \%$ soy bioplastic and $67 \%$ PLA was a superior material for containers compared with the blend of 33\% soy bioplastic and 67\% PHA. The superior fertilizer effect of the soy-PLA biocomposite could be the result of PLA being less degradable than PHA, and thus providing a more favorable $\mathrm{C}: \mathrm{N}$ ratio for controlled nutrient release. When comparing blends of PLA and PHA with 33\% soy bioplastic, PLA was a better copolymer for container production, indicated by higher nutritional content in plants and better structural integrity for soy-PLA biocontainers during crop production. All soy-PLA biocontainers maintained integrity for the entire duration of the experiment, but containers made of soy-PHA degraded too quickly and began to lose structural integrity before the end of the experiment.
We conclude that soy-composite bioplastics have strong potential for use as sustainable alternatives for replacing the petroleum plastics commonly used in manufacturing of plant containers. In our trials, the fertilizer effect was particularly promising when growing marigold in biocontainers made from equal parts soy bioplastic and PLA. Plants produced in these biocontainers when fertilized with $60 \mathrm{mg} \mathrm{N}$ were of equal or greater dry weight than plants grown in petroleumplastic containers fertilized with five times the amount of fertilizer $(300 \mathrm{mg} \mathrm{N})$. The fertilizer function of soy-biocomposite containers could allow growers to reduce or eliminate the application of supplemental fertilizer. Along with the potential to improve sustainability, this added function should be attractive to growers for its potential to reduce the costs and labor related to fertilizer application.

\section{Literature Cited}

Beeks, S.A. and M.R. Evans. 2013a. Growth of cyclamen in biocontainers on an ebb-and-flood subirrigation system. HortTechnology 23:173176.

Beeks, S.A. and M.R. Evans. 2013b. Physical properties of biocontainers used to grow longterm greenhouse crops in an ebb-and-flood irrigation system. HortScience 48:732-737.

Botts, B. 2007. Beauty and the plastic beast. Chicago Tribune. 21 Aug. 2014. <www.chicagotribune. com/chi-garden-plastic-story, 0,389835 .story>.

Calabria, L., N. Vieceli, O. Bianchi, R.V.B. de Oliveria, I. do Nascimento Filho, and V. Schmidt. 2012. Soy protein isolate/poly(lactic) acid injection-molded biodegradable blends for slow release of fertilizers. Ind. Crops Prod. 36:41-46.

Currey, C., J. Schrader, K. McCabe, W. Graves, D. Grewell, G. Srinivasan, and S. Madbouly. 2014a. Bioplastics for greenhouses-Soy what? GrowerTalks 77(9):70-74.

Currey, C., J. Schrader, K. McCabe, W. Graves, D Grewell, G. Srinivasan, and S. Madbouly. 2014b. Soy containers: Growing promise, growing plants. GrowerTalks 77(10):60-65.

Evans, M.R. and D. Karcher. 2004. Properties of plastic, peat, and processed poultry feather fiber growing containers. HortScience 45: 1232-1237.

Grewell, D., G. Srinivasan, J. Schrader, W. Graves, and M. Kessler. 2014. Sustainable materials for a horticultural application. Plast. Eng. 70:44-52.

Groot, W.J. and T. Borén. 2010. Life cycle assessment of the manufacture of lactide and PLA biopolymers from sugarcane in Thailand. Intl. J. Life Cycle Assess. 15:970-984.

Helgeson, M.S., W.R. Graves, D. Grewell, and G. Srinivasan. 2009. Degradation and nitrogen release of zein-based bioplastic containers. J. Environ. Hort. 27:123-127.

Helgeson, M.S., W.R. Graves, D. Grewell, and G. Srinivasan. 2010. Zein-based bioplastic containers alter root-zone chemistry and growth of geranium. J. Environ. Hort. 28:74-80.

Hermansson, F. 2013. Environmental evaluation of bio-composites using LCA. MS Thesis, Chalmers Univ. Tech., Göteborg, Sweden.

Koeser, A., G. Kling, C. Miller, and D. Warnock. 2013a. Compatibility of biocontainers in commercial greenhouse crop production. HortTechnology 23:149-156.

Koeser, A., S.T. Lovell, M. Evans, and J.R. Stewart. 2013b. Biocontainer water use in short-term 
greenhouse crop production. HortTechnology 23:215-219.

Kratsch, H.A., J.A. Schrader, K.G. McCabe, G. Srinivasan, D. Grewell, and W.R. Graves. 2015. Performance and biodegradation in soil of novel horticulture containers made from bioplastics and biocomposites. HortTechnology 25:119-131.

Kuehny, J.S., M. Taylor, and M.R. Evans. 2011. Greenhouse and landscape performance of bedding plants in biocontainers. HortTechnology 21:155-161.

McCabe, K.G., J.A. Schrader, S. Madbouly, D. Grewell, and W.R. Graves. 2014. Evaluation of biopolymer-coated fiber containers for containergrown plants. HortTechnology 24:439-448.

NatureWorks LLC. 2013a. About natureworks. 21 Aug. 2014. <http://www.natureworksllc.com/ About-NatureWorks-LLC.aspx $>$.

NatureWorks LLC. 2013b. From plants to plastics. 21 Aug. 2014. <http://www.natureworksllc.com/ The-Ingeo-Journey/Eco-Profile-and-LCA/HowIngeo-is-Made $>$.

Pelletier, N., N. Arsenault, and P. Tyedmers. 2008. Scenario modeling potential eco-efficiency gains from a transition to organic agriculture: Life cycle perspectives on Canadian canola, corn, soy, and wheat production. Environ. Mgt. 42:989-1001.

Pelletier, N., E. Audsley, S. Brodt, T. Garnett, P. Henriksson, A. Kendall, K.J. Kramer, D. Murphy, T. Nemecek, and M. Troell. 2011. Energy intensity of agriculture and food systems. Annu. Rev. Environ. Resources 36:223-246.

Razon, L.F. 2014. Life cycle analysis of an alternative to the haber-bosch process: Nonrenewable energy usage and global warming potential of liquid ammonia from cyanobacteria. Environ. Prog. Sustain. Energy 33:618-624.

Schrader, J.A. 2013. Report on the annual consumption of plastics for specialty-crop containers in the United States. 21 Aug. 2014 $<$ http://www.public.iastate.edu/ bioplastic/ Supplementary/AnnualPlastic.html>.

Schrader, J.A., K.G. McCabe, D. Grewell, and W.R. Graves. 2015a. Bioplastics and biocomposites for sustainable horticulture containers: Performance and biodegradation in home compost. Proc. GreenSys2015-International Symposium on New Technologies and Management for Greenhouses. Acta Hort. (In press).

Schrader, J.A., K.G. McCabe, G. Srinivasan, K. Haubrich, D. Grewell, S. Madbouly, and W.R. Graves. 2015b. Development and evaluation of bioplastic containers for sustainable greenhouse and nursery production. Acta Hort. 1104:79-88. Schrader, J.A., G. Srinivasan, D. Grewell, K.G. McCabe, and W.R. Graves. 2013. Fertilizer effects of soy-plastic containers during crop production and transplant establishment. HortScience 48:724-731.

U.S. Department of Agriculture. 2014. Floriculture crops 2013 summary. 18 Nov. 2015. <http://www. nass.usda.gov/Charts_and_Maps/Floriculture_ Crops/florsales.php>.

U.S. Department of Agriculture. 2015. National nutrient database for standard reference-release 26. 18 Nov. 2015. <http://ndb.nal.usda.gov/ndb/ foods/show/5000?fg=Legumes+and+Legume + Products $\&$ man $=\&$ llface $=\&$ format $=\&$ count $=\&$ $\max =25 \&$ offset $=225 \&$ sort $=\&$ qlookup $=>$.

U.S. Environmental Protection Agency. 2013. Plastics. 21 Aug. 2014. <http://www.epa.gov/wastes/ conserve/materials/plastics.htm $>$.

Yang, S., S.A. Madbouly, J.A. Schrader, G. Srinivasan, D. Grewell, K.G. McCabe, M.R. Kessler, and W.R. Graves. 2015. Characterization and biodegradation behavior of bio-based poly (lactic acid) and soy protein blends for sustainable horticultural applications. Green Chem. 17:380-393. 